\title{
GeNeT E O MAL: SARTre ENTRE A ÉTICA E A ESTÉTICA
}

\author{
Marcelo Prates ${ }^{1}$
}

Resumo: Este artigo tem por objetivo apontar uma relação entre a estética e a ética em Sartre, mostrando que a constituição ética do indivíduo não se distingue da sua constituição estética. Primeiramente, parte-se da crítica que Merle faz em seu artigo à psicanálise existencial e se evidencia como o encontro com a história e a postulação de uma teoria da personalização nas obras biográficas destituem tais críticas. Num segundo momento, legitimam-se as postulações anteriores, apontando-se como na obra Saint Genet Sartre ratifica a constituição do gosto sobre a moral pelo processo de personalização. Por fim, será visto que toda ética tem um pressuposto transgressor, na medida em que o sujeito ético é também sujeito estético.

Palavras-chave: Sartre. Genet. Ética. Estética. Personalização.

\section{INTRODUÇÃo}

A filosofia de Sartre é perpassada pelo problema moral. Toda sua discussão inicial tem por base a questão da crise metafísica e cultural que seu tempo expressou, cuja ressonância maior à moral foi a impossibilidade de uma fundamentação absoluta da mesma. No entanto, tal crise intensifica também sua necessidade, ao menos sobre suas reais condiçóes iminentes, de sorte que a permanência da questáo se reflete pela própria ambiguidade da sua impossibilidade e da sua necessidade (SARTRE, 2002, p. 185 - nota 4; 2007, p. 130). Assim, ela é sempre indicada, mas, ante tal contexto de crise, é sempre apresentada em reflexôes parciais, inacabadas, constantemente variáveis em seus elementos. $\mathrm{Na}$ tentativa de totalização dessas dissonâncias, ela é, no mais frequente, compreendida em três momentos maiores, a saber: a primeira, de $O$ ser e o nada aos Cadernos para uma moral, a segunda correspondente às reflexóes que pautam a história e o

\footnotetext{
${ }^{1}$ Professor substituto na Universidade Estadual do Centro-Oeste (UNICENTRO), Guarapuava, PR Brasil. (D) https://orcid.org/0000-0001-5180-6053 E-mail: marceloprates1@gmail.com

Doutor em Filosofia pela Universidade Federal do Paraná (UFPR).
}

http://dx.doi.org/10.1590/0101-3173.2019.v42n3.11.p191 
marxismo, cujos apontamentos maiores aparecem na Crítica da razáo dialética e, por fim, as entrevistas dos últimos anos, sobretudo as concentradas em Pouvoir et liberté; sem, no entanto, chegar a uma determinação final sobre a questão. Por um lado, fica difícil uma determinação fechada e sistemática sobre o problema por outro, essa abertura e fragmentação constante permitem uma diversidade de aportes a respeito da questáo.

Nosso objetivo, neste artigo, não é dar nenhuma resposta definitiva a esse problema, todavia, apontar como, em sua obra, por meio de suas postulaçóes posteriores, a saber, o encontro com a história e a teoria da personalizaçáo desenvolvida sobretudo nas obras biográficas e em especial nos estudos sobre Flaubert, se propicia uma aproximação da estética com relação à ética. Isso nos possibilita entrever não uma solução às discussôes morais, mas nos dar um aporte para uma compreensão possível à determinação da escolha, determinação essa de interesse não só do fenomenólogo ou do psicanalista, mas também do moralista. Isso ensejará aferir que tipo de sujeito é o sujeito ético e qual sua possibilidade moral. Ora, é nesse problema da determinação da escolha que, em $O$ ser e o nada, encontramos a proximidade dessas abordagens, visto que Sartre sobressalta o caráter moral da escolha, apontando o seu sentido ético (SARTRE, 2007, p 674). Nossa hipótese é de que a determinação da escolha tem sua proeminência na base sensível e imaginária mais que reflexiva, de modo que quando a reflexão ocorre, é justamente tendo essa base já alicerçada: a isso Sartre chamou de necessidade da liberdade, lugar privilegiado da constituição passiva do indivíduo que, mesmo na sua passividade, não deixa de se constituir. Nesse caso, a decisão tem um sentido ético, porém, a facticidade de sua constituição não é tomada na sua tessitura de valores universais nem por alguma subordinação ao dever, senão na medida de tensão entre esses valores e o indivíduo em sua constituição. Isso nos leva à necessidade de considerar duas dimensóes ausentes nas análises sobre tal problema, em $O$ ser e o nada. Uma é a historicidade do indivíduo, salientada, sobretudo, na Crítica da razão dialética, mas já presente de forma evidente no ensaio sobre Genet, e a teoria da personalização, postulada nos escritos biográficos, principalmente o de Flaubert. Como Saint Genet condensa esses dois pontos, é nele que nos pautaremos para tal análise. Partindo de tais pressupostos, procuramos evidenciá-los nessa obra, por ser ela uma análise concreta daquilo que seria apenas postulado nas obras teóricas e que, por conta disso, tornavam as reflexóes abstratas, contrariando os propósitos latentes do existencialismo de jamais abandonar o nível de tal concretude. 
Para isso, iniciamos pela discussão que Merle faz, em seu artigo, sobre a psicanálise existencial em Sartre, uma vez que as críticas ali dirigidas poderiam se endereçar às nossas hipóteses, resolvendo assim, de início, aquilo que poderia vir a se apresentar depois como questionamento. Nesse caso, é em função da crítica ao seu posicionamento que justificamos o nosso. Ademais, por conta da limitação do artigo, alguns elementos são mais pressupostos e nosso trabalho toma-os em seus sentidos mais imediatos, sem maior aprofundamento, o que certamente renderia maiores discussóes, por se tratarem de noçôes definidas por Sartre, entretanto, não explicitadas por ele de forma mais precisa, tais como a constituição passiva e a necessidade da liberdade. O objetivo é mostrar como Sartre resolve isso, nas suas análises biográficas, ao invés de partir de uma análise sobre o imaginário ou das determinaçôes ontológicas do nada. Ademais, veremos que essa estética endereçaria talvez um novo escopo de abordagem sobre o problema ético em Sartre para além dos já indicados e, sobretudo, àqueles que resguardam todo ranço metafisico que sua filosofia, especialmente na fase inicial, não conseguiu abandonar.

\section{ENTRE A ÉTICA E A ESTÉTICA}

Uma das tarefas da psicanálise existencial era tentar extrair o sentido ético dos vários projetos humanos. Descrever o ser dessa escolha e seu teor moral levaria Sartre muito mais a uma "tipologia dos modos de existência fundamentais" (FRAJOLIET, 2005, p. 5), ou mais simplesmente a uma "tipologia das pessoas" (MERLE, 2005, p. 1), que à constituição ou fundamentação de um modo de agir supra-histórico. De fato, Sartre não tem a pretensão de uma moral a-histórica e sempre transpareceu isso, em suas reflexôes, nos Diários, nos Cadernos para uma moral, Verdade e existência, Saint Genet etc. Nesse caso, a base fáctica, além de se tornar o solo de referência dos valores, é sempre histórica e o desejo não se manifesta senão na concretude histórica enquanto horizonte concreto da liberdade. Ante isso, a determinação da escolha não ocorre de forma reflexiva sobre os possíveis e os valores da época do indivíduo, mas estes são constituídos desde a tenra infância, cuja interiorização não é feita senão enquanto processo de personalização dos mesmos. Nesse caso, é sob tal processo que o sentido ético das escolhas deve ser investigado. Esta é, por certo, uma das tarefas da psicanálise existencial.

Ora, em seus primórdios, em $O$ ser e o nada, a psicanálise existencial carece ali desse desenvolvimento, sendo sua última análise relativa ao proble- 
ma do gosto e da qualidade. E é justamente com base nesse pressuposto que Merle, em seu artigo, analisa a relação entre juízo moral e juízo de gosto em Sartre, mostrando como Sartre subverte a relação entre eles: "A escolha de ser não significa, portanto, de nenhuma forma a escolha de regras de ação, mas um julgamento de gosto que tem, segundo Sartre, uma significação moral." (MERLE, 2005, p. 8). Assim, Sartre subverte a relação entre moral e estética que considera o juízo de gosto como uma projeção do juízo moral. Se, para Kant, o juízo estético simboliza o juízo moral, para Sartre, "o juízo de gosto constitui o conjunto do juízo moral" (MERLE, 2005, p. 9). Segundo a ideia kantiana que explica tal relação pela projeção interior, e que Sartre associa à opiniâo comum, o sujeito teria primeiramente a experiência de certas atitudes e condutas morais que o desagradaram e que ele as condena, e separadamente uma intuição do viscoso, dada antes ou depois daquela. Entáo, ele posteriormente as associaria e só assim o viscoso se apresentaria como símbolo de toda uma classe de sentimentos e de atitudes humanas (SARTRE, 2007, p. 650). Sartre rejeita tal ideia pela impossibilidade de associação posterior, já que nada explicaria por que o viscoso, na sua pureza material, teria de ser associado a um sentimento que lhe é totalmente alheio. É impossível, logo, para Sartre, compreender tal pureza material dissociada desde sua origem de uma qualidade afetiva. Daí que, para ele, a explicação por projeção seja também uma petição de princípio, porque só poderia formar a imagem dessa unidade, se essa imagem já fosse previamente estabelecida. Assim, não haveria pureza de sentimento e de qualidade, porém, uma qualidade que sempre surgiria já carregada na sua materialidade por uma afetividade e vice-versa. Merle pretende acusar que, dessa forma, Sartre teria esquecido que o sentimento moral se refere menos aos gostos e pensamentos puros que às maneiras de se comportar concretas de outros seres humanos ou às nossas próprias açóes (MERLE, 2005, p. 8).

A consequência disso, que segue como segundo argumento de Sartre contra a opinião comum, é que os juízos de gosto já estão presentes na criança, enquanto os juízos morais ainda são necessários que ela os aprenda. Ora, se é permitido denotar o juízo de gosto como constitutivo é porque ele surge antes da condição do juízo moral, desde a tenra infância. Mas é justamente na distinçáo entre a infância e a vida adulta que Merle (2005, p. 9) sinaliza o problema dessa teoria, pois, para Merle, além de ser realmente as crianças as que mais têm contato com tal materialidade, como no exemplo trabalhado por Sartre, o viscoso, Sartre mesmo daria exemplos de avaliaçôes positivas das pessoas ante essa materialidade e não somente repulsivas. $\mathrm{O}$ problema maior aqui seria não o de Sartre considerar o viscoso um exemplo de má-fé, porém, 
fazer do viscoso o próprio símbolo da má-fé (MERLE, 2005, p. 9), transferido às diferenças entre as determinaçóes na infância e a vida adulta para as distintas formas desses juízos, os quais não mais se implicaria uma homogeneidade do gosto, nesse caso, a necessária repulsa pelo viscoso.

Ora, certamente tais objeçóes fazem jus à filosofia de Sartre. Aqui, encontramo-nos ainda no início da teoria. Nela, Sartre já reconhece a unidade entre psíquico e qualidade, mas não a personalização enquanto passagem singular da infância ao adulto, ou melhor, da proto-história à pessoa singular, e também a unidade entre matéria histórica e a historicidade do indivíduo, não ao menos com toda envergadura que elas requerem para ocupar tal lugar na teoria. A facticidade ali permanece abstrata, mas também como uma exigência, pois requer sempre a dimensão singular da situação em sua concretude. Ao exigir para a compreensão da liberdade o em-si na concretude da situaçáo, Sartre já não poderia ter tomado o viscoso com a densidade ontológica que lhe concedeu, embora seja preciso reconhecer o papel do elemento naquele momento da teoria e a necessidade de pensar uma base de princípios para a psicanálise existencial.

Ademais, como dizer que os símbolos são psiquizados desde a infância? Sartre responderia que, fazendo a biografia de um indivíduo, sua psicanálise existencial, averiguando seu projeto de ser. E Sartre certamente jamais dispensaria todo peso que tal qualidade traz em sua dimensão histórica, dado que o universal é singular e histórico e a matéria carrega em si essa universalidade e historicidade, embora vivida singularmente. E apontaria desde como isso ocorre na base familiar até a constituição social assumida nas demais camadas sociais; tal seria a tarefa das mediaçóes e das disciplinas auxiliares do método progressivo-regressivo. Frente a isso, o viscoso seria destituído de sua forma mais abstrata e geral e reconduzido ao peso próprio da história e da singularidade dos agentes, segundo a qual, para continuarmos no exemplo de Sartre, na obra, o açúcar já não apareceria tão somente como um fato contingente, contudo, na singularidade a que a história o conduz, como, por exemplo, sua disponibilidade econômica, o seu uso, os modos singulares de uso familiar e regional, as situaçóes com as quais a criança entra em contato com ele e as demais formas de viscoso etc. Uma tarefa quase-infinita para uma tematização, mas não para a compreensão, seja social, seja de um indivíduo, seja de nós mesmos.

É a esse ponto do quase infinito que Merle dirige sua crítica final: "Sartre considera o objeto do juízo de gosto como uma totalidade e, no entanto, o julga ao mesmo tempo sob o ponto de vista de uma qualidade determinada, a saber, o ponto de vista exclusivo do viscoso, e, portanto, da fluidez e da 
solidez" (MERLE, 2005, p. 9), obrigando tal teoria a afirmar que "todas as qualidades de um objeto são representadas por uma única dessas qualidades", as quais passariam a ser consideradas por Sartre como "a matéria do sabor" (SARTRE, 2007, p. 661). Sartre pensa ali algumas formas mais elementares, como o viscoso (SARTRE, 2007, p. 560) e mesmo o buraco (SARTRE, 2007, p. 559), como determinadas categorias existenciais como base dos projetos genéricos da realidade humana (SARTRE, 2007, p. 660), como a tendência a preencher dos buracos e a destruiçáa no ato de comer, o que fundamentaria até certo ponto as críticas de Merle. Ora, Sartre não rejeita esses projetos genéricos que essas categorias existenciais denotam, mas os atribui à condição humana, condição cuja dimensão material é determinada historicamente. Por isso, na medida em que o pensamento de Sartre se encaminha mais e mais para o concreto, através da história e da personalização, tal crítica já perde sua força.

Além disso, a confusão entre totalidade e qualidade específica se deve justamente a essa confusão entre a qualidade pura e mesmo à hierarquização que dela decorre no sujeito, esse composto de mil qualidades. Sartre mesmo reconhece que "essas qualidades se unem a determinadas características temporais do sabor, ou seja, a seu modo de temporalização" (SARTRE, 2007, p. 661), portanto, sua concretude histórica. E, se a diversidade de símbolos não representa de forma alguma uma multiplicidade de projetos de vida individuais (MERLE, 2005, p. 9), é porque a individualidade se constitui ante a forma singular de assumir esses símbolos. Daí que, esquecendo tal constituição singular, só reste a Merle concluir que Sartre apenas se interesse pelos objetos enquanto formas de apropriação do em-si pelo para-si, cujas formas elementares serão a boa-fé e a má-fé. Todavia, se Sartre não considera a hipótese por projeção, é porque pensa a unidade singular do projeto pessoal a essas formas materiais que não são irredutíveis ao sujeito, mas justamente o solo sob o qual se deve interrogá-lo sobre seu ser próprio, sua singularidade. Assim, "se soubermos interrogá-los, eles nos revelam os projetos fundamentais da pessoa" (SARTRE, 2007, p. 661), e entre a "arquitetura complexa" do sabor e sua "matéria diferenciada", deveríamos reencontrar, na unidade dessa complexidade e diferença, a qualidade própria do sujeito. É essa apropriação do em-si "sob as espécies de uma qualidade singular" (SARTRE, 2007, p. 662) que poderia nos fornecer as bases sociais e ontológicas da compreensão, como pensou Sartre, ao associar determinadas características mais constantes às mais singulares, como a passividade em Flaubert e o mal em Genet. E, como a ontologia de Sartre se torna cada vez mais concreta, náo faria sentido fazer uma topologia, não das singularidades individuais, entretanto, das diferentes 
formas simbólicas elementares, as materialidades e qualidades puras, como a fluidez da água (mesmo associando a qualidade a uma matéria específica, como colocamos), qualidade que certamente não seria predominante numa região polar ou muito quente. Por isso, é preciso restituir a concretude da concepção como noçáo temporalizada e que dimensiona todo teor metafísico da qualidade, que já deixa de ser metafísico no sentido tradicional, por apontar a finitude à situação a qual a envolve.

No entanto, seria a teoria da personalização ${ }^{2}$ que viria a preencher as outras ausências que Merle (2005, p. 9) aponta, qual seja, o exame dos outros aspectos da vida psíquica e aquele do psiquismo em geral, pois, por ela, o psíquico não é distinto do ato de liberdade que o engendra, mas justamente é por tal ato que ele se constitui, em outras palavras, não há psíquico para além da matéria pela qual ele se engendra, senão a fórmula estrutural da consciência e da vivência, mas a qual, por sua vez, evidencia que matéria e forma não são senão que constituiçôes da singularidade: "Forma e conteúdo são a mesma coisa: é este conteúdo que exige esta forma." (SARTRE, 2002, p. 547). Por isso, no lugar de uma teoria do psíquico, teríamos aqui toda uma análise baseada em noçôes ${ }^{3}$ e a rejeição do idealismo (SARTRE, 2013, p. 52), as quais não poderiam ser constituídas de maneira independente do objeto que elas iluminam. A busca

${ }^{2}$ Quando falamos em teoria da personalização, nós nos referimos às formas de análise e estruturas dialéticas que Sartre postula, em suas investigaçôes biográficas. Consistindo em três momentos essenciais do processo, a saber, a constituição passiva, a personalização e o espírito objetivo, a personalizaçáa compreende o processo todo pelo qual o sujeito institui, por sua liberdade, a forma de sua singularidade. É por isso que, segundo Mouillie (2000, p. 63), como fruto das suas autocríticas, consolidadas especialmente a partir de Genet, Sartre realiza uma reabilitaçâo da vida psíquica, no sentido de que imbrica o indivíduo (ser um) com sua personalização (ser tal). Assim, a partir de então, "visar a existência sobre o aspecto de sua finitude" significa "aceitar uma personalidade" (MOUILLIE, 2000, p. 62). Logo, o indivíduo enquanto fazer é consolidado como "um processo dinâmico e dialético" (BORNHEIM, 1998, p. 50) que envolve tanto a liberdade mesma quanto a alienaçáo, por tratar-se de uma composição de ser, que se afirma sempre mais na medida em que se faz. $\mathrm{O}$ fazer, por conseguinte, é ratificação crescente da escolha, porque "constituição e personalização perfazem uma totalização" (BORNHEIM, 1998, p. 50). Nesse sentido, a personalização pressupóe a constituição, embora a passagem de uma para outra não seja pautada por uma cronologia de acontecimentos, senão de constituiçấo de si, dos gostos subjetivos: "De fato, nâo se trata tanto dos acontecimentos de nossa vida, mas do modo como eles se dão e como nós os acolhemos." (SARTRE, 2014, p. 1382, grifo nosso). Assim, no processo de constituição e personalização, "individuação e personalização se intercruzam. A impessoalidade da consciência absoluta se encontra ultrapassada pela historialização de cada um em sua práxis." (MOUILLIE, 2000, p. 66).

3 É preciso frisar que, sobretudo em seus estudos biográficos e na passagem à Crítica, Sartre faz uso não mais de conceitos, universais e atemporais, mas de noçôes. Nas palavras do filósofo: "Por noção entendo a compreensão global, mas estruturada, de uma realidade humana que faça a temporalização - como devir orientado - entrar na apercepçáo sintética que ela queira ter de seu objeto e, ao mesmo tempo, de si mesma." (SARTRE, 2014, p. 1821). 
pelo "grau zero" da "gênese dessa sensibilidade" (SARTRE, 2013, p 50) não é feita a partir de uma condição ontológica, mas da criança concreta, pois há nesse momento uma unidade entre o intencional e o orgânico, sentido e matéria (SARTRE, 2013, p. 53), que faz da sensibilidade o motor de todo campo simbólico psíquico, pois a criança "interioriza os ritmos e os trabalhos maternos como qualidades vividas de seu próprio corpo" (SARTRE, 2013, p. 56).

Se havia uma confusão sobre esse grau zero entre a impossibilidade de apreendê-lo e a necessidade disso, ele não só se torna fator fundamental da compreensão da personalizaçáo, como aponta sua achega primeira, sua facticidade junto à qual ele se enraíza no mundo como negatividade: "O que a criança interioriza, nos dois primeiros anos de sua vida, é a Genitrix por inteiro; isso náo quer dizer que ele se assemelhará a ela, mas que será feito, em sua singularidade irredutível, pelo o que ela é." (SARTRE, 2013, p. 59). Daí que Sartre tenha que se referir que é preciso também consultar a história pessoal de Caroline Flaubert. Por um lado, a história pessoal dela revela suas singularidades, por outro, temos ali padrôes gerais da mãe burguesa.

Entretanto, toda essa forma de análise é temporalizada e depende de formas particulares de relações de parentesco, relações históricas e singulares. Assim, se Sartre elabora uma tentativa de "esclarecer o vivido com a luz negra da infância" (SARTRE, 2013, p. 55), ele sabe que, "sem a restituição dos fundamentos arcaicos da sensibilidade, ela fica no ar, abstrata e relativamente indeterminada" (SARTRE, 2013, p. 53). Porém, se o método já se mostrava frágil, na proximidade dos primeiros anos, torna-se mais difícil ainda. Sartre interpreta a passividade em função da estrutura familiar, mas reconhece que essa se manifesta mais veemente dos cinco aos nove anos. Antes disso, tudo é ainda obscuro, pois cada acontecimento singular, na sua multiplicidade e complexidade da situação composta, pode causar reaçóes difíceis de serem estabelecidas por mera causalidade, como se, ao ser virado de costas, arrancado cedo demais do seio, "como ele se descobrirá? Brutal ou brutalizado?" (SARTRE, 2013, p. 56). Ora, sendo o pequeno indivíduo desde seu surgimento uma negatividade que se constitui, que se forma, sendo ele desde já sua situação inteira, então "é a situação total que decide" (SARTRE, 2013, p. 56) e por conta da variabilidade do papel do corpo (SARTRE, 2013, p. 57), não se prende à possibilidade de uma garantia sobre dados que possam ser estabelecidos como conceitos psíquicos a priori. Por isso, Sartre diz que o papel do acaso aqui é predominante e fica impossível estabelecer variáveis fixas. Mas o 
objetivo de Sartre não é estabelecer variáveis gerais, senão aquelas linhas singulares que determinam um indivíduo singular:

O que procuramos aqui, nós, é a criança de sorte, o encontro de certo corpo com certa mãe: laço náo-compreensível visto que duas séries se encontram sem que possamos explicar o cruzamento; e, ao mesmo tempo, compreensão primeira, fundamento compreensível de toda compreensão: de fato, essas determinaçóes elementares, longe de somarem ou afetarem uma à outra em aparência, são imediatamente inscritas no campo sintético de uma totalização [...] Por fim subimos o curso dessa vida até o seu começo: nós a interrogamos sobre o primeiro acaso ultrapassado, isto é, sobre a característica fundamental de seu destino. (SARTRE, 2013, p. 59, grifo nosso).

Aqui encontramos, no acaso, o peso da contingência, mas um peso criador $^{4}$, um peso que não torna a realidade opaca, senão condição de fuga dessa opacidade numa nova singularidade concreta, cuja distensão temporal é aprofundamento de sua constituição primeira sobre uma variável própria. Essa variável, como sua qualidade fundamental, e sendo que "a síntese compreensiva só se encerra na morte" (SARTRE, 2013, p. 55), certamente nos é mais bem acessível quando do termo final descemos aos seus primórdios, isto é, tomamos seu percurso dialético. Sendo o indivíduo uma totalidade, o estrutural e o temporal se confundem, o que nos possibilita o acesso a essa qualidade, na medida em que sua vida nos revela seu acontecimento fundamental: "A chaga é uma injúria sofrida, portanto um acidente de sua temporalização, e, ao mesmo tempo, que ela faz a priori parte de seu ser intemporal." (SARTRE, 2013, p. 46). É por isso que Sartre chamará de constituição passiva a qualidade de Flaubert, sua passividade ou estupidez, "essa vertigem, esse desgosto de viver, essa impossibilidade de nada empreender, essa dificuldade de negar, de afirmar, que lhe proíbe a entrada no universo do discurso" (SARTRE, 2013, p. 46) e verá na relação fria com a mãe, que certamente é intensificada nos dramas da família Flaubert, sobretudo na figura do pai e na relação que este estabelecia com o primogênito, a causa profunda dessa qualidade.

${ }^{4}$ Com relação a isso, para Sartre, "quando se trata da pessoa humana, o acaso é ele próprio produtor de sentido; o que quer dizer, em geral, que a existência assume a facticidade sem conseguir fundá-la e, em cada caso particular, que qualquer indivíduo deve poder se manifestar como homem de acaso (insignificante) ou de um certo acaso (supersignificante); é o que Mallarmé nos explica em 'Um lance de dados' [...] O lance de dados jamais abolirá o acaso, pois ele contém o acaso em sua essência prática." (SARTRE, 2013, p. 58). 
Mas estamos aqui apenas nos primórdios da qualidade. Flaubert se fará passivo, contudo, o que realmente interessa a Sartre são os modos pelos quais ele escapa à passividade, constituindo-se enquanto tal, qual seja, sendo o autor de Madame Bovary. Tudo se volta à necessidade de compreender sua investida e esta como sendo o modo livre pelo qual se volta às suas condiçóes de base, as quais o lançam à necessidade da liberdade, que nada mais é que $o$ clamor por sua singularidade. As dificuldades de estabelecer esse primeiro acaso não impedem sua possibilidade e mesmo sua necessidade. Sartre reconhece a cautela que se deve ter em analisar uma proto-história e mesmo de quais meios se deve inventar para dar conta das suas lacunas até chegar à compreensão do objeto (SARTRE, 2013, p. 18). Há, na análise de Flaubert, um privilégio de acesso que são seus textos. Em todo caso, tal restituição é possível, mas não fundamental, pois, se o psíquico é ele mesmo construído, basta que seja possível iluminar as condiçôes sociais e o acontecimento singular de tal constituição, para que ela já seja suficiente para determinar a qualidade fundamental, mesmo sem o acesso imediato às primeiras formas, porque, se tudo é um aprofundamento do mesmo e a compreensão é do todo, se poderá restituir entre a regressão e a progressão a qualidade singular da pessoa. Essa qualidade é justamente essa totalização singular da situação como modo pelo qual a pessoa se forma e pela qual se hierarquizarão desde cedo as matérias do sabor, as quais repetirão posteriormente a forma da sua real resposta, se se tornara bruto ou delicado, que tipo de delicadeza, se sua feminilidade é uma resposta a isso etc.

Tal é o caso de Genet, de cujos primeiros anos não dispomos de maiores informaçóes, mas cujo acontecimento fundamental, aos nove, remete-nos àquilo que será compreendido por Sartre como sua qualidade singular. É nele também que encontraremos como Sartre melhor estabelece as relaçôes entre a ética e a estética, na singularidade do indivíduo. Aqui a teoria da personalização dá conta de explicar o caráter de decisão moral incluída em tal juízo de gosto, pois, se a primeira crítica de Merle visava justamente a essa ausência, a personalizaçáo associa essa necessidade de liberdade à escolha de si mesmo, pois tal escolha já não se estabelece mediante um único ato reflexivo ou mesmo à instantaneidade do cogito, mas à construção de toda uma vida. Nesse sentido, os gostos são modificados na medida em que tal escolha também se modifica a cada nova determinação em sua singularização. Não que ela implique o abandono do projeto primitivo, posto que é singularização do mesmo, mas unicamente que ela não cessa de se refazer, se diferenciar, na unidade da mesma singularização. É reclamando essa singularidade que podemos compreender como a estética pode se sobrepor à moral, moral que objetiva justamente 
homogeneizar e destituir as singularidades dos atos, moral que condiz à rigidez séria do social.

No fundo, uma análise moral dos atos deveria conduzir às condiçóes que engendram tal ato, mas tal base constitutiva nos revela justamente uma formação da liberdade cuja experiência é decisiva para toda constituição livre posterior, isto é, é essa base sensível e vivida que fundamentará a decisāo ética do indivíduo. ${ }^{5}$ Como no caso de Flaubert, onde a frieza da máe é sentida e não julgada, ela aparece como uma sensação e gosto do mundo e não no seu vislumbramento prático e moral, como posteriormente julgamos como "a frieza da máe". Vemos aqui uma espécie de moralização daquilo que é vivido como sensação e imaginação, e pelo mundo fáctico ser constituído ante esses universais, haveria uma prioridade da moral sobre a estética. No mundo adulto, fica fácil separar significante de significado, todavia, na infância, isso se confunde, e tudo vem na forma da sensibilidade singular. Aqui a moral náo tem outro fundamento senáo a má-fé e o espírito de seriedade, ainda que advindos da pressáo do mundo. No entanto, estaríamos contrariando a experiência primeira da criança, de modo que tal julgamento chega só muito tarde para ela, que certamente absorverá também tal preceito mundano, mas aceitará na condição do seu projeto já iniciado como necessidade de sua liberdade, o que fará ainda, caso não sucumba ao espírito de seriedade, que seus gostos primeiros prevaleçam ante tal julgamento ou interfiram neles.

Tudo se passa como se o psíquico fosse construído nessa base que é a infância, base da proto-história e constituição passiva do indivíduo, segundo as sensaçôes que ele interioriza e pela qual será formada a base de sua singularidade, cujo processo é indefinido, porém, que será tomado como uma resposta, uma solução inédita a essa chaga. Tudo isso é vivido como uma escolha de si, dada a necessidade da liberdade, mas para os quais os juízos morais são exteriores e fatores de alienação, visto que se baseiam sempre na rigidez e universalidade do preceito mundano e histórico, cuja efusão é o adulto. A decisão aqui reverte somente sobre o indivíduo, porque ele é escolha de si e do mundo, isto é, por sua singularidade, à qual a moral só poderá ser mais um fator exterior de pressão e sobre o qual tal vida singular será uma resposta sobre o lugar próprio desse valor moral que tenta se preservar, se será ele já ultrapassado ou ainda

5 Para maior clareza, compreendemos aqui a moral como um conjunto de regras e valores socialmente e historicamente estabelecidos, e a decisão ética como aquela escolha determinada pela singularidade do indivíduo. Nossa hipótese é de que a decisão ética não se distingue da decisão estética, dada a maneira como se opera a constituição passiva do indivíduo e sua personalização. Por fim, isso conduz a própria vida, no seu desenrolar, à sua beleza e sua condição tanto de transgressora como de transformadora da moral. 
necessário, se ele violenta ou acalenta etc. É o que encontramos em Genet. Sua biografia mostra, além de sua libertação e toda a constituição da sua época e sua forma singular de libertação, sua qualidade própria, como se opera essa relação entre moral, ética e estética, seja no âmbito da libertação própria, seja no tratamento geral para a compreensão da personalização.

\section{GENET E O MAL}

$\mathrm{O}$ acontecimento de Genet que o tira da infância, que institui sua cha$\mathrm{ga}^{6}$, é uma pressão moral que ele, naquele momento, só o é capaz de receber sensivelmente. Ele não compreende de que é culpado, não há a interiorização da culpa como algo que escapa ao dever-ser, senão como apreensão qualitativa do olhar do outro. "Eis o enredo desse drama litúrgico: um menino morre de vergonha ${ }^{7}$, em seu lugar surge um marginal; o marginal será possuído pelo menino." (SARTRE, 2002, p. 15). Ele náo tematiza aqui o julgamento e suas condições, mas sofre passivamente a sua constituição como "natureza perversa" (SARTRE, 2002, p. 79). Natureza, porque será sempre ressuscitada para todo novo ato de roubo que lhe dará seu impulso inicial e sobre o qual cada nova variação a tomará como base:

Genet quer arrancar o poder constituinte desse olhar, comete seus roubos deliberadamente, como desafios e atos constitutivos. Cada um deles será ao mesmo tempo um furto particular e utilitário e uma cerimônia que ressuscita a crise original, na ausência da testemunha. Com essa cerimônia, Genet se dá simbolicamente a sua natureza de ladrão, é uma repetiçáo da crise e do rito de passagem, uma morte seguida de ressureiçáo. A cada vez, o menino se mata para ressuscitar ladrão diante de testemunhas imaginárias. Roubava porque 'era' ladrão, agora, é para ser ladrão que ele rouba. Roubar, agora, para ele, é consagrar a sua natureza de ladrão pela aprovação soberana da sua liberdade. É por isso que ele

\footnotetext{
${ }^{6} \mathrm{O}$ fato poético é instaurador da singularidade. Ele acontece certamente na pressão fáctica como uma resposta a essa pressão. Confuso, no seu desenrolar na vida, ele encontrara sua imagem própria, sua diferença: "A queda é a descoberta da "diferença" através do julgamento dos outros. É isto que Flaubert quer sugerir; um menino monstruoso conhece, apesar de tudo, a idade de ouro da primeira infância, ele estará sozinho: alimentado, protegido, por certo, mas nunca comparado. E então, um dia, aos sete anos, um juiz soberano descobre sua particularidade e a aponta a ele: ei-lo outro." (SARTRE, 2013, p. 188).

7 Sobre tal objetivação, a seguinte passagem serve para complemento: "Os acontecimentos que nos chocam se desenrolam ao mesmo tempo em todos os níveis da nossa vida mental e, em cada nível, se expressam em uma linguagem diferente. Um estupro verdadeiro por se tornar, na nossa consciência moral, uma condenação iníqua, mas inevitável e, inversamente, uma condenação pode ser sentida como um estupro. Ambas transformam o culpado em objeto, e se este sente a sua objetivação, no seu coração, como uma vergonha, ele a sente no seu sexo como um coito imposto." (SARTRE, 2002, p. 89).
} 
chamará, mais tarde, o roubo de ato poético. Realmente, é preciso compreender o termo no seu sentido originário de poiein: pelo roubo, Genet recria para si a sua natureza, consagrando-a ao mesmo tempo. (SARTRE, 2002, p. 79, grifo nosso).

Aqui encontramos a criança de sorte, porque foi nesse ato, contingente, que Genet se fez e se assumiu como ladrão. Sartre aponta que, se fossem outros os anos, aos dezessete, onde se rompe com os pais (SARTRE, 2002, p. 32), fase mais madura, tudo seria apenas uma anedota incômoda. Entretanto, nesse primeiro ato, sua resposta não é uma resposta moral, é a fuga mais imediata tomada na confusão das sensações: ele corre, e correrá para sempre: "Filho sem mãe, efeito sem causa, Genet realiza na revolta, no orgulho, na infelicidade, o soberbo projeto de ser causa de si." (SARTRE, 2002, p. 79, grifo nosso). Por certo, Sartre não é alheio a toda liberdade de Genet constituída antes do acontecimento primordial, a acusação do roubo. Mesmo não dispondo de muitas informaçóes, ele aponta alguns elementos que denotam todo um estado anterior, afinal, Genet cometia pequenos roubos. Embora nada disso pudesse definir que ele seria ladrão, como várias outras crianças que roubavam não o foram, trata-se aí mais da situação da época do que de um desvio de caráter.

Primeiramente, o fato é que Genet não tem mãe, e isso marcará a imagem da mulher que figurará nos seus livros sempre como mãe, "a Deusa-mãe" (SARTRE, 2002, p. 21), que o rejeita e o abandona: "O menino adivinha que uma mulher arrancou-o de si, vivo e ensanguentado, para jogá-lo fora do mundo, e sentir-se maldito. Desde o nascimento ele é o mal-amado, o inoportuno, o excedente. Indesejável até no seu ser, não é o filho dessa mulher: é seu excremento." (SARTRE, 2002, p. 21), sensação que, segundo Sartre, o levará a se comparar sempre à imagem do lixo e do imundo. É dessa imagem, em seus textos, que Sartre chega às sensaçóes juvenis, mesmo sem maior base material para isso. Essas sensaçóes são sempre caracterizadas como uma "inquietação sem rosto nem consistência lhe parece um traço de humor sem importância; Genet não a percebe" (SARTRE, 2002, p. 20). Não a percebe, mas compreende, sabe que algo não está bem, embora não consiga tematizar esse mal-estar (SARTRE, 2002, p. 20), devido aos vocabulários que lhe emprestam, "fastos e piedosos", e que "se aplicam muito mal ao que ele é e ao que sente" (SARTRE, 2002, p. 20, grifo nosso). Genet, a todo momento, "pressente que é suspeito em particular", pois sendo "filho de ninguém" (SARTRE, 2002, p. 21) sua simples existência "já perturba a ordem natural e a ordem social" (SARTRE, 2002, p. 20). 
Esse mal-estar se estenderá por toda sua vida: a ausência da mãe se complica, quando esta é associada à falta de posses. Não tendo mãe, não possuirá herança. Essa linguagem fasta e piedosa pertencia aos filhos legítimos, não a Genet. Sendo enviado ao campo, "por cúmulo do infortúnio" (SARTRE, 2002, p. 23), a imagem do homem rural é a imagem particular de uma "sociedade que define o ser pelo ter" (SARTRE, 2002, p. 22). Aqui a imagem do homem é associada à sua terra: "Tem-se o bem porque se é herdeiro legítimo e, reciprocamente, é-se modelado pelo que se tem." (SARTRE, 2002, p. 23). $\mathrm{O}$ respeito à propriedade será a lembrança de não possuir uma mãe, e a falta da propriedade implicará o lugar da própria existência: "O menino Genet quer ter para ser.” (SARTRE, 2002, p. 22). Não a doação que o casal de agora lhe faz. Justamente porque dão, lembrarão Genet de que ele "tinha a obrigação de ser agradecido a eles" (SARTRE, 2002, p. 22), agradecimento que marca a devida distância, a qual, para o filho legítimo, o pai teria o dever de mantê-lo: Genet "não era filho deles" (SARTRE, 2002, p. 22).

É essa condição que levará Genet a brincar de santo e de ladrão. Pela primeira brincadeira, dá sua resposta ao abandono da mãe, tomando o misticismo como uma forma de recusa da ordem humana: "Criança abandonada vinga-se admirando os filhos que abandonam pai e mãe para seguir o Cristo." (SARTRE, 2002, p. 23). Do mesmo modo, também roubar é apenas uma forma de se designar como verdadeiro proprietário (SARTRE, 2002, p. 24). Ademais, "Genet condena o roubo!" (SARTRE, 2002, p. 27); sendo uma criança, não possui ali uma estratégia de ação sobre o social, "pensa menos em roubar do que em fazer experiências imaginárias de apropriação" (SARTRE, 2002 , p. 24, grifo nosso). No fundo, trata-se de dois modos como a criança procura substituir a mãe ausente e a propriedade inexistente, mas sem todo cunho moral que os adultos viráo lhe impor:

Para a criança que rouba e para a criança que se masturba, existir é ser visto pelos adultos, e já que essas atividades secretas ocorrem na solidão, elas não existem. A verdade é que ensinaram ao pequeno Genet uma moral que o condena. Ele acredita nela com toda a sua alma, mas, por isso mesmo, ele se destrói, pois essa moral de proprietário o repele duplamente para o nada: como pé-rapado e como filho ilegítimo. Essa é a chave da sua conduta e das suas desordens: à luz do dia, ele é claro, honesto, feliz; entretanto, quanto mais afirma sua felicidade na luz, mais se arruína e se tortura na sombra. Vai reduzir-se ao desespero. Se rouba, sonha com a santidade, não é contra a moral camponesa, mas por causa dela. Recorre a essa dupla atividade compensadora por náo poder liquidar um sistema de valores que recusa o seu lugar ao sol. (SARTRE, 2002, p. 28). 
Contudo, o mundo do adulto é o mundo dos valores, dos signos sociais. Genet é lançado desde sempre como fora do ser, do bem, portanto, da moral. Ela lhe dá a verdade de sua alteridade, de seu não pertencimento ao ser. Assim, no momento em que é sentenciado sobre o olhar dos outros, o marginal é assumido como condição: "Genet é um ladrão: essa é a sua verdade, a sua essência eterna.” (SARTRE, 2002, p. 30). Aqui a condenação moral é também atribuição de uma qualidade objetiva, Genet rouba, logo, é mau. Rouba porque é mau, e não "é mau porque rouba". Aqui o objetivo representa os valores universais vigentes na sociedade. No entanto, a subjetividade, o modo como esse valor objetivo é tomado e sentido, definirá não a tessitura do universal, mas o clima interior com que Genet interioriza tais condiçôes e onde seu mal-estar adquire sua forma manifesta: "O acontecimento inicial decretou o clima interior de Genet: será o horror.” (SARTRE, 2002, p. 16). Isso porque, a partir daí tanto Genet será constantemente recobrado ante tal momento, como ele mesmo reviverá às suas custas esse momento, denotando um "sentido metafísico" (SARTRE, 2002, p. 44) àquilo que pertence aos quadros sociais. Se ladrão é uma noção (SARTRE, 2002, p. 49) e, portanto, sua origem é social, ela se transmuta como sua essência pela nomeação que ele recebe:

Disso resultou uma metamorfose radical da sua pessoa e da sua linguagem. Por essa nomeação cerimoniosa, que o transformava a seus próprios olhos em objeto sagrado, dava-se a partida a essa lenta progressão que faria dele, um dia, um 'príncipe dos ladrôes' e um poeta. Mas, agora, ele está longe de suspeitar que escreverá, que terá orgulho em fazer o mal. Prostrado, perplexo, apenas sofre. (SARTRE, 2002, p. 55, grifo nosso).

Se a personalização é um processo que aponta a escolha de si, em Genet, essa escolha é realizada de antemão pelos outros, que lhe denotam algo que ele ainda mal compreende. É a partir da acusação inicial que ele fará seus esforços para ser, por sua decisão, o que os outros decidiram que ele seria. "E, sem dúvida, há isso na sua decisão" (SARTRE, 2002, p. 71), ainda que seja "um papel cujas réplicas já estão fixadas" (SARTRE, 2002, p. 71). Ora, é na decisão de ser ladrão e não somente na imposição que há nessa apreensão confusa, nessa sensação acompanhada de horror, uma decisão ética em que ele transforma "uma situação de fato ('Sou excluído do grupo') em um imperativo ético ('Logo, devo tomar a iniciativa da recessão')" (SARTRE, 2002, p. 66, grifo nosso), porque o impele a agir, uma ação sobre si, já que, nesse momento, a única coisa que lhe cabe é o sofrimento. Mas todas essas sensações de horror não são destituídas da sua tessitura prática, mesmo na sua 
passividade. Aqui acontece o que Sartre chama de "estágio ético da revolta, é a dignidade [...] A dignidade faz da passividade um desafio e apresenta a inércia como uma revolta ativa." (SARTRE, 2002, p. 66). Assumindo ser o que fizeram dele, Genet não apenas aceita passivamente essa qualidade objetiva, mas a toma e faz por si, com seus sentimentos. Aqui o imperativo indica a liberdade, porque não há razão para a adoção de tal atitude, senão de que ele adota tal atitude "com o coração" (SARTRE, 2002, p. 61). Tal medida apenas nos alude à singularidade da escolha, que implica na elevação de sua escolha ao patamar moral da qual ela é repugnada: "A dignidade de Genet é a reivindicação do mal.” (SARTRE, 2002, p. 66).

Com isso, Sartre associa o ato poético ao imperativo ético, porque a cada momento Genet terá de recobrar seu ser primeiro, mesmo sob as metamorfoses que ele virá a sofrer, deverá ser ele mesmo. Porém, sendo inventado, tal imperativo irá se confundir com a pessoa mesma de Genet, com seu estilo, portanto, com sua liberdade. Ele quer isso, busca isso, procura sempre o pior, sempre ser o outro. Se o roubo é seu ato poético, se é ele que o faz ladrão, ele não apenas roubará, como um gesto que se desfaz depois que se realiza, caindo no fracasso de ser. Para Genet, seu ato é sua aventura e, se o recupera a cada instante, não é só pelo valor que ele institui, mas para ele mesmo ser esse ato: "Ele não diz que roubará, mas que será o ladrão. Esse ladrão é substância 'ladroante’ como a alma é substância pensante.” (SARTRE, 2002, p. 74). Será ladrão. não para roubar, mesmo que roube para sobreviver, mas para assumir toda qualidade que tal ação lhe traz. Essa qualidade que está associada a todos seus sentimentos de baixeza, abjeção, perversão, enfim, o contrário de tudo aquilo que qualifica os que o acusaram, enfim, tudo o que faz de Genet $o$ outro. Assim, é para ser 0 outro que ele rouba:

Em suma, é a regra, nele e fora dele, da vontade do outro. Não de algum outro em particular, nem mesmo de todos os outros, mas daquilo que em cada um é outro, diferente de si mesmo, diferente de todos. $\mathrm{O}$ mal é o outro e é ele mesmo, enquanto é para si mesmo outro diferente de si; é a vontade de ser outro e de que tudo seja outro, é o que é sempre outro, diferente daquilo que é. ${ }^{8}$ (SARTRE, 2002, p. 36 e 37, grifo nosso).

\footnotetext{
${ }^{8}$ Logo, a escolha tem um caráter ético, mas não moral, porque justamente se faz outra, isto é, fora da conjuntura histórica aceita socialmente. Há uma transgressão moral, a qual tem seu sentido ético da escolha livre de si, cujo fim é uma forma de viver, portanto, de valor, mas para o qual a vida em sua luta será uma aposta para a sua universalização. No mais, exteriormente, é um valor que irrompe; interiormente, para Genet, trata-se de sua forma de ser, de sentir, de viver.
} 
A singularidade de Genet começa com essa diferença imposta, com sua exclusão do ser. Esses homens trocam seu pertencimento ao ser pela negação da sua condição criadora, fazendo-se zeladores do velho museu do mundo. Essa alteridade revela a inquietação, a negatividade latente, é a própria condição do horror. A ela "o homem de bem se castra: arranca da sua liberdade o momento negativo e projeta para fora de si essa víscera sangrenta. Eis a liberdade cortada ao meio." (SARTRE, 2002, p. 35). Genet encarna a imagem dessa liberdade na sua volúpia e não que ele o queira "por intençóes deliberadas da sua consciência" (SARTRE, 2002, p. 45, grifo nosso), mas porque lhe é exigido "que ele reconheça essa vontade má como inspiradora dos seus desejos cotidianos, das suas vontades ordinárias" (SARTRE, 2002, p. 45). Assumindo o mal, ele se deleita no horror, ele passa a querer ser tudo aquilo que é repugnado pela ordem do ser, pela máquina social. Esse outro, ainda sem nome, esse mal vazio se tornará lentamente aquela forma poética do mal. Aqui o outro, como diferença imposta, se torna diferença criada e assumida, porque, se dizem que ele é mal, ele o será por sua forma, por sua liberdade, e nisso sim se fará diferente, diferente do que dizem que é, diferente por sua singularidade. A princípio, sua expulsão é ao mesmo tempo o fundamento da sua projeção e mesmo mais, "direi até que ele [o mal] é ao mesmo tempo o fundamento e o objetivo de toda atividade projetiva" (SARTRE, 2002, p. 40). Ora, essa atividade projetiva enquanto revolta ética implica ao mesmo tempo a objetividade e universalização do horror, do mal, contudo, segundo a dialética com o singular:

Por mal entende-se, simultaneamente, o ser do não-ser e o não ser do ser. As mesmas razóes darão origem à segunda antinomia, pois o mal, sendo primeiro outro, diferente do ser, é relativo em sua essência, mas como ele é outro absolutamente e não sob este ou aquele aspecto particular, é preciso que ele seja um absoluto à sua maneira. Absoluto e relativo, tudo ao mesmo tempo, ele é simultaneamente princípio abstrato e uma vontade singular. (SARTRE, 2002, p. 37).

A exigência da alteridade demanda que Genet não somente assuma o mal de que o acusam, mas faça dessa alteridade sem forma a sua imagem singular. Imagem construída pelo processo de personalização, ela não se consumirá no mero roubo ou na perversidade. Ora, Sartre aponta que o mal, sendo o não-ser do ser, só pode ser contemporâneo a ele. Genet bem compreende isso, e deseja a perpetuação das instituiçôes como finalidade da sua própria perpetuidade. No entanto, se a assunção do mal é também a da singularidade, Genet não poderá ser meramente mau: "Um mau que se quer mau só conse- 
gue realçar a moral social, pois confessa que o mal é abominável.” (SARTRE, 2002, p 171). A esse mal, as boas consciências não são atingidas nem incomodadas. A saída de Genet, feita lentamente, será a construção de uma sofística contra o homem honesto (SARTRE, 2002, p. 47). É somente nessa singularidade que se assume com radicalidade o mal, pois, do contrário, ele também imitaria o bem (objetivo universal). $\mathrm{O}$ bem aparece como ação universal e institucionalizada, carente da liberdade, assumida segundo o prático-inerte. Há nessa adesão um "abandono" (SARTRE, 2002, p. 160) da singularidade e a constituição do "sujeito universal" (SARTRE, 2002, p. 160), o sujeito comum. Enquanto indivíduo, nada anula a singularidade, e as formas subjetivas e vividas implicam modos variados como esse meio universal é assumido. $\mathrm{Na}$ sua forma geral, ele assume uma condição moral, porém, sua assunção singular acarreta sua subjugação aos gostos subjetivos. "É ela, é a singularidade, é a solidão que visamos obter, não o mal por si mesmo." (SARTRE, 2002, p. 162). Nesse sentido, embora a revolta ética aluda à eleição de um imperativo ético, é à liberdade que ela visa, mas uma liberdade contra o ser, contra o bem. Assim, é na escolha ética que a moral mostra sua ambiguidade:

Assim, o vencido se arranca à contingência original e se torna valorsujeito. A sociedade recupera esse valor-sujeito depois de alguns anos de purgatório e o utiliza para provar que há no ser outra coisa diferente do ser, um resíduo inexplicável quando tudo está explicado, Melhor ainda: o fracasso se torna a essência do homem. $\mathrm{Na}$ verdade, o valor tem duas exigências contraditórias: por um lado, é preciso tentar inscrevê-lo no ser e, por outro lado, ele exige ser situado além de toda realizaçáo. A essa dupla exigência, o agente moral só pode satisfazer, ao que parece, dando a sua vida para realizar o imperativo ético e morrendo por não ter atingido seu alvo. (SARTRE, 2002, p. 189).

Sendo fator não de queda e anulação, mas de criação e diferenciação, de mudança, a singularidade, ao assumir na sua afirmação de si que se é outro que o ser, coloca a moral como o solo do qual se parte e ao qual se chega, mundo instituído e mudança institucionalizante, todavia, cujo ponto de chegada, pelo processo mesmo de saída do interior do ser como negatividade, faz com que todo processo carregue em si a forma desse novo campo, indo contra o ponto de partida. ${ }^{9}$ Submersa no campo fáctico cujo prático-inerte denota

\footnotetext{
9 Aqui a singularidade só pode ter como resultado o novo, daí que não seja com vistas à moral que a açáo é realizada, mas só o pode ser contra ela. Nesse aspecto, estaríamos às voltas com um novo estado de alienação, mas tal estado não desagua no exterior inerte e alienante, ele traz em si uma diferença que é a própria pessoa. Assim, aqui a pessoa se reconhece enquanto tal, nesse novo estado, e sua
} 
um universo de valores universais, como o ser, cada singularidade é levada por sua ocasião própria a assumir tal entorno para além dele. Como são eles a matéria viva da liberdade, a sua forma e medida de mudança, esse sujeito ético constitui inevitavelmente o universo moral. Encontramos aqui o movimento dialético da cultura, uma cultura que custa a liberdade de seus provedores e para os quais não delega nada, além da solidão ontológica e histórica de seu empreendimento. Vindo da alienação, caindo numa outra construída por seu próprio movimento de insurreição, o para-si se perde no seu fracasso. Livre, ele ganha perdendo e perde ganhando. Ganha sua liberdade à custa dela mesma.

Ora, o não de Genet não é somente um empreendimento do mundo, é também de si: "A essência objetiva do menino sendo o não, Genet deu-se uma personalidade dando-se a subjetividade do náo." (SARTRE, 2002, p. 557). Ao se fazer outro, sendo esse movimento relativo e absoluto - absoluto, porque se ergue contra o ser, e relativo, porque implica a singularidade do movimento - é vivido justamente como um gosto, como um sentimento próprio, enfim, como subjetividade. Aqui o sujeito ético implica o sujeito estético, porque a personalidade é todo o ato poético como qualidade fundamental. O sujeito expressa um valor, mas um valor que é construído ao seu sabor. Ademais, tudo ali é vivido como diferença e singularidade na pessoa mesma de Genet (SARTRE, 2002, p. 557), só depois virão os universais: "O roubo, a pederastia, a traição como conteúdo [objetivo] dessa essência singular.” (SARTRE, 2002, p. 557).

Essa diferença sentida pelo menino desde sempre como seu mal-estar do mundo, intensificado sempre mais pela sociedade que o colocava no seu lugar, isto é, fora deles, intensificado no acontecimento que o expulsa de sua infância, não deixa de se prolongar até o fim de sua virulência: o "sentimento de ser diferente o levou ao roubo; agora é esse mesmo sentimento que torna a sua condenação menos terrível" (SARTRE, 2002, p. 64). Menos terrível, porque assume esse horror e, para assumi-lo, é preciso se tornar o que se é, e o que se é, é o mais diferente de todos os outros: "Para se tornar o mais insubstituível dos seres, é preciso renunciar ao particular para se tornar uma relação singular com a totalidade do real." (SARTRE, 2002, p. 205). Sob esse ponto, escapa-se a todo valor, porque, sendo singular, não há padrão de medida cabível senão

liberdade agora se confunde com a sua alienação. Esse encontro-escolha denota um ser positivo do qual o fracasso é posto em condição secundária. "O para-si é um encontro-escolha, ou seja, define-se como escolha de fundamentar o ser do qual é encontro. Significa que o para-si, enquanto empreendimento individual é escolha desse mundo, enquanto totalidade de ser individual; não o transcende, ruma a uma universalidade lógica, mas sim rumo a um novo "estado" concreto do mesmo mundo." (SARTRE, 2007, p. 644, grifo nosso). 
aquele mesmo em que se inventa, o que o coloca fora da moral. É isso que Genet compreenderá: é uma criança que é, "no mais profundo de si mesma, um outro diferente de si" (SARTRE, 2002, p. 46) e que levará o menino a requerer no seu roubo a sua especificidade, "seu mal específico" (SARTRE, 2002, p. 225, grifo nosso). Aqui encontramos aquele problema, apontado por Merle, entre a totalidade do sabor e suas determinaçóes. Nesse caso, a partir dos pressupostos que indicamos, toda a construção da sua personalidade é dada, justamente por isso, na sua especificidade. Se é mal, não é somente sobre a forma de valor historicamente instituída como mal, mas se faz mal segundo sua especificidade, e a conquista da sua liberdade não é senão a postulação dessa especificidade: Genet, o poeta do crime.

Assim, a passagem de uma alienação a outra é o ser mesmo da pessoa, e essa pessoa requer para si uma especificidade como sua qualidade fundamental. Se o fracasso é a tessitura própria da finitude não é porque ele se esvazia na individualidade, porém, justamente porque encontra ali sua condição absoluta. E não se trata de uma finitude que se perde no seu movimento de sujeito absoluto e que se dissolve na constelação dos universais, mas que se ergue absoluta segundo seu movimento. Aqui o valor-sujeito é compatível ao sujeito estético, porque a criação acarreta uma dissolução imaginária do real para a construção de si. A imagem universal é tomada como a imagem de si como esse universal, é a mim que tal valor implica primeiramente, para só depois ser inserido no ser e no prático-inerte, porque sua origem é projetada, contudo, uma projeção que exige a criação e a imaginação, na medida mesma em que ela vai se realizando.

Aqui a vida imaginária corrobora o processo de criação e singularização da liberdade. Se, nessa investida, ela não se perder no mundo imaginário, se conseguir se impor ante o real e sua opressão, ela será vitoriosa e conseguira marcar o mundo. É o caso de Genet. Ele imagina em cada roubo uma cena que prefigura a cena primeira, com todo seu público, seu corpo exposto (SARTRE, 2002, p. 333). Seus gestos ali cintilam todo o seu ser, visto que o constituem. Ali o roubo se transforma não apenas num meio de sobrevivência, mas numa "destruição sagrada" (SARTRE, 2002, p. 251), ela é uma invasão ao homem, ao bem. A invasão é real, há o roubo. Mas, para Genet, é imaginariamente que ele acontece: "O mal não se faz, imagina-se. Aí está a solução de todas as suas contradiçóes. $\mathrm{O}$ mal radical não é escolha da sensibilidade, mas do imaginário." (SARTRE, 2002, p. 340). Desenrolando-se no real e no imaginário, seu ato é para ele poético (SARTRE, 2002, p. 333). Genet brinca com 
a cena do crime, para realizar a sua condição. Aqui a imaginação dimensiona toda a simbologia da matéria, por ela, Genet escapa e constrói sua condiçáo. ${ }^{10}$

Podemos agora compreender a aventura de Genet. Esse homenzinho enérgico e ativo se consagrou ao louco empreendimento de se tornar o que já é e destruir o que não pode se impedir de ser. Imediatamente, a sua vontade se volatiza no imaginário. Já que ela quer o que não se pode querer, é que ela sonha o que quer. Destinadas, por natureza, a permanecer ineficazes, suas destruiçôes e suas aprovaçôes ocorreram simbolicamente. A partir do dia em que escolheu querer seu destino, Genet decidiu, sem saber, se fazer símbolo, se exprimir por símbolos e viver no meio dos símbolos. (SARTRE, 2002, p. 332).

Com sensaçôes que não encontram lugar mais no mundo, mundo que na criança de sorte serviu de base mesma dessas sensaçôes, ele constrói pela imaginação um mundo em que elas caibam. Entretanto, Genet não se consumirá no imaginário. Tal ato náo deixa a realidade neutra, ele se inscreve no ser como gesto. Há uma estratégia de Genet em usar essa inércia da matéria para suportar seus sonhos (SARTRE, 2002, p. 398). Sua inscrição se consolida, quando Genet chega ao máximo de seu ato, a poesia. Do ladrão ao sonhador, do sonhador ao poeta, ele "será o ladrão que se tornou poeta" (SARTRE, 2002, p. 335), porque a poesia é "o melhor meio de fazer o mal e destruir o ser. Será poeta porque é mau.” (SARTRE, 2002, p. 335). É na poesia que o mal trará toda uma nova estética, na medida em que provoca uma nova iluminação no ser: "Essa iluminação é a beleza. Mas entendamos: a beleza não aparece primeiro para provocar depois a irrealização do ser; ela é o processo mesmo da irrealização." (SARTRE, 2002, p. 358). Daí que o gesto do artista se distinga do texto do poeta, mas não da estilização do mal por Genet, já que, se a beleza que expressa esse mal singular não é apenas uma "propriedade objetiva dos gestos", é porque ela "exige ser uma virtude dos pensamentos" (SARTRE, 2002, p. 360). Essa virtude não é a do bem, da ordem já dada, mas da liber-

\footnotetext{
${ }^{10}$ Não se trata de criar um mundo imaginário para tal possiblidade, mas, antes, que a imagem atesta a condição criativa da liberdade. Ademais, "o problema da criação ontológica permanece no estado de mistério. Com efeito, se o mundo fosse não criado, só haveria ser e nós mesmos estaríamos de todo condicionados por nossa facticidade; mas se, pela imagem, somos capazes de pôr o real a serviço do nada, é porque não nos limitamos àquilo que somos, e esse nada que produzimos exige uma explicação que não pode ser dada." (SARTRE, 2014, p. 1598).
} 
dade na singularidade da sua necessidade. Se há uma irrealização da ordem do ser, é porque há uma realização da ordem de si. ${ }^{11}$

É nesse sentido que a vontade aqui não aparece como vontade do belo, mas bela vontade (SARTRE, 2002, p. 360), cuja disposição é a liberdade mesma. E se a revolta ética leva à eleição de um imperativo ético, a forma assumida na singularidade denota à beleza essa finalidade, em outras palavras, o imperativo ético é também um imperativo estético. Com efeito, a irrealização como mal exige uma imposição do gesto sobre a ordem resistente, denotando um valor, mas um valor que é contrário ao ser. $\mathrm{O}$ valor é o ponto de encontro entre ética e estética, encontro que só pode ser contra o ser, numa nova irradiação do seu fracasso, portanto, como elaboração do sentido subjetivo. Logo, "o esteta é uma oblação, inventa sacrifícios sublimes e grotescos para que a beleza seja; desnuda-se e mostra suas chagas para transformá-las em joias" (SARTRE, 2002, p. 368), enfim, engrandece o outro diante do ser. Por isso, se há uma moral aqui, oriunda dessa negatividade, ela é caudatária a essa beleza, cuja exigência demanda não uma submissão à alienação, mas sua constituição enquanto uma "moral da sensibilidade" (SARTRE, 2002, p. 360). Aqui o juízo prático não pode ser dissociado da ação má, da beleza que é requerida nesse ato de irrealização e criação. Vê-se o mundo, no entanto, apenas se consegue vê-lo na lente da beleza latente, na forçada inscrição no ser, na difícil relação entre essa negatividade incisiva e o ser que a engendra e a emperra. Esse paradoxo da ação, o qual não é confluente à moral ordinária, mas representa uma sensibilidade criadora própria, criadora de valores outros que não estes, faz da arte algo vivo: “'A arte', diz Genet, 'de fazer você comer merda'. Essa beleza não é fácil: exige uma tensão de todos os instantes, um esforço contínuo para manter juntos esses dois termos - imundície e joia - que se repelem; ela esgota." (SARTRE, 2002, p. 369).

Dessa forma, seu projeto ético é também personalidade estética, de modo que, mesmo na variação, no refinamento do estilo, o objetivo permaneça sem-

\footnotetext{
${ }^{11}$ Aqui a ordem e harmonia da totalidade que proporciona a beleza é confluente não ao mundo, mas ao sujeito. Essa certamente é uma constante na filosofia de Sartre. "Assim, a beleza é a singularidade no seu arrojo temporal: não entendo por beleza somente o prazer sensual dos instantes, mas antes a unidade e a necessidade no curso do tempo. Os ritmos, as repetiçóes de períodos ou de refrãos me tiram lágrimas as formas mais elementares da periodicidade me comovem. Noto que esses desenvolvimentos regrados devem ser essencialmente temporais, pois a simetria espacial me deixa indiferente [...] que esse evento seja belo, isto é, que ele tenha a necessidade esplêndida e amarga de uma tragédia, de uma melodia, de um ritmo, de todas essas formas temporais que avançam majestosamente, através das repetiçốes regras, para um fim que elas levam em seu flanco. Expliquei tudo isso em $A$ náusea." (SARTRE, 2005, p. 343).
} 
pre o mesmo: "É preciso inquietar o homem honesto, fazer com que o chão lhe falte, fazê-lo duvidar da moral e do bem.” (SARTRE, 2002, p. 360). Assim, é para si que Genet se irrealiza, mas sua liberdade constituída pelo olhar do outro enquanto encarna o ser, se dirige a eles. Sua imposição não pode ser por sua condição, que não lhe é dada pelo próprio Genet, porém, por eles, por sua singularidade. É Genet que reordena o ato e faz o mundo infestado por seu mal. Aqui a função prática do exercício do mal é substituída por uma qualidade singular, ela se sobrepóe à ordem do ser, ou melhor, é sua nova ordem:

Mas uma liberdade só tem uma maneira de se dirigir a outra liberdade: exigir. Se Genet sente, no fundo de si mesmo, que a beleza lhe diz respeito, é que ela exige dele, como o mal, as condutas mais difíceis. Ela exige que ele viva segundo a sua lei, essa lei que Wilde, príncipe dos estetas, chamava de estilo e Genet de elegância. 'Nos assuntos de grande importância', diz o primeiro, 'o elemento vital não é a sinceridade, é o estilo'. E o segundo: 'Sua elegância é o único critério de um ato'. A elegância: a qualidade de uma conduta que transforma em parecer a maior quantidade de ser." (SARTRE, 2002, p. 360, grifo nosso).

Essa aparência, transformação do mundo, no cenário de Genet, faz com que a sociedade tome tais imagens para si e, por uma inversão, é ela que lhes conferirá a sua objetividade. Porém, é Genet que exterioriza com a força da sua singularidade. Não que nos demais não ocorra essa singularização, mas, assumidos pelo signo do ser, só conseguem reproduzir sua alienação e massificação ante o arrefecimento da sua singularidade. Aqui "o esteta se tornou artista ou potência nua de produzir imagens nos outros" (SARTRE, 2002, p. 515). Sua singularidade impera em face do apagamento das demais tornadas sujeito-comum, enquanto público que assiste o artista. O fim de Genet é ele mesmo, mas também o ser, é a sua integração a ele, tal como o ideal de valor apregoa. Todavia, assumido seu máximo de ser, sua singularidade irredutível como outro que náo o ser, ele inscreve essa qualidade como transformação do fato cultural, em outras palavras, "ele tentará integrá-los ao espírito objetivo e fazer com que sejam consagrados como fatos culturais" (SARTRE, 2002, p. 397). Essa consagração culminará pela inscrição poética.

A passagem do artista ao poeta não implica uma mudança do quadro do esteta. Por certo, pela poesia, Genet se verá livre "das insuportáveis obrigaçóes do estetismo" (SARTRE, 2002, p. 515), deixará de ter um "papel a desempenhar" (SARTRE, 2002, p. 515). Todavia, trata-se mais de forçar uma imagem no espírito objetivo. Pela escrita, ele consegue impor aos Justos as suas 
imagens, pela poesia, "esse morto social decide vir, em pessoa, 'assombrar' a comunidade das pessoas honestas" (SARTRE, 2002, p. 399). Sua imposição assume as formas do imperativo categórico pelas palavras, forçando seus leitores a adotá-lo. Essa forma imperativa sobre as palavras ${ }^{12}$ é a própria beleza (SARTRE, 2002, p. 468), o estilo mesmo de Genet, é por ela que os leitores são conduzidos àquilo que eles repugnam. A estratégia é diferente, mas, entre o esteta e o artista, entre o gesto e o texto, Genet é a condição dessa beleza, pois ele figura como "estrutura interna da obra [...] seu livro é ele." (SARTRE, 2002, p. 509). Seu estilo é a expressão da sua composição própria, ele "é o próprio Genet. Compor, para ele, é recriar-se.” (SARTRE, 2002, p. 509).

Genet se recria, isto é, volta a afirmar seu acontecimento originário, mas sem seu erro, sem sua fuga de horror. Aqui ele não é como os outros o viam, mas tal como ele quer ser, ante sua condição primeira. Ele lhes entrega de volta a imagem que lhe deram, força-os a assumir o que lhe dão, contudo, agora segundo sua liberdade: "O meio no qual o homem pode e deve se tornar o que é, é a consciência dos outros." (SARTRE, 2002, p. 514). E nada afere mais a tais consciências que a escrita. Antes, o mal era o oposto do bem e dependia deste, eram "contemporâneos". Como poeta do mal, o roubo ganha outra roupagem, o ladrão age em outro campo e instaura outra forma de relação com as pessoas honestas (SARTRE, 2002, p. 514). Nesse momento, não há nem bem nem mal, Genet avança para além do ser, o roubo se desfigura e se transforma no tempo, para além do tempo. Por sua liberdade, ele qualifica o roubo por sua singularidade, na medida em que se impóe enquanto singularidade:

Ladrão, Genet servia a ordem estabelecida, poeta do roubo, ele a destrói. Seus delitos náo conseguiram perturbar a consciência do justo; mas a representação do delito nos atinge até os ossos. Se ele tem razão, tudo é falso; somos galinhas gordas que esperam ser comidas, morreremos iludidos. Contra o crime, nossa polícia e nossos especialistas sáo proteçóes eficazes; contra a verdade poética do crime, não temos nenhuma defesa,

\footnotetext{
${ }^{12}$ Por certo, a liberdade é um ato existencial que engloba toda a vida do indivíduo, daí que não seja um privilégio dos escritores, embora Sartre se concentre mais nesse tipo de atividade. Genet não é somente um ladrão, é um poeta, e é por ser um poeta do crime que reconhecemos sua singularidade, porque ele é um objeto que manifesta de forma mais expressa sua condição de universal singular (SARTRE, 1994, p. 62), ao trazer ao texto tudo o que é vivido por ele (SARTRE, 1994, p. 63). Sendo ele, em vida, "uma encarnação diferente do mesmo todo (mundo interiorizado)" (SARTRE, 1994, p. 64), é por seus escritos que intensificou essa diferença. Enquanto artista, era para si, no seu público imaginário, que manifestava sua singularidade, depois, poeta, esse mal e essa beleza carregam essa mesma singularidade nos seus romances e no alcance mundano que eles trazem. Essa diferença que é seu estilo e que, bem sabemos, não é uma comunicação de um saber (SARTRE, 1994, p. 67), mas a tessitura do esforço singular de ultrapassagem de toda época (SARTRE, 1994, p. 68).
} 
pois ela se situa além das causas e do ser, pois ela é o inapreensível triunfo daquele que nossos cães de guarda já reduziram à impotência. (SARTRE, 2002, p. 465).

Se a passagem entre bem e mal figura a personalidade, ela é o signo dessa singularidade, seu como. Esse recriar-se como caminho de superação do bem e do mal é a libertação de Genet (SARTRE, 2002, p. 399). Ele se liberta, ao se fazer, indo de uma alienação a outra, até à sua potência completa, até o limite que ela mesma pode engendrar. Compreendendo que se tornou pelo outro, fez de si esse outro segundo uma nova roupagem. Toda sua qualidade resulta nessa obra e nos dá a ver tal imagem, a qual nos toca pela beleza, mas cuja fonte nos é inominável, cuja vivência escapa ao campo temático, ao mesmo tempo em que nos revela as fontes dessa singularidade: "Quem quisesse descrevê-la e nomeála voltaria sempre a nomear a operação ou a descrever a obra; mas ela é mais e é outra coisa, pois produz a obra e é consciência da operação. Conhecemos essa consciência criadora: é a existência." (SARTRE, 2002, p. 519). Mas é por essa diferença que conseguimos ter o acesso a essa negatividade nua. Ali é que encontramos a sua potencialidade. $\mathrm{Na}$ obra bela, como em sua estrutura interna, Genet "não é nada mais do que uma liberdade sem rosto que arma ciladas fascinantes para outras liberdades" (SARTRE, 2002, p. 519). Aqui, a liberdade é tomada pela liberdade e o sentido do ser não se sustenta enquanto sentido único, nos levando a confrontá-lo como abertura histórica pela diferença que a singularidade lança. Tal impulso faz da queda e do fracasso a condição do impulso criador. E não há aqui nenhuma intenção moralizadora, nem mesmo essa saída do fracasso possibilita a moral. A moral é sempre da ordem do ser, do bem. Não se trata de encontrar um solo para a moral. Embora as obras de Genet se apresentem "como experiências éticas sistematicamente conduzidas" (SARTRE, 2002, p. 523), ele "nunca pensou em tornar-nos melhores e não deseja que tiremos proveito de suas liçóes" (SARTRE, 2002, p. 523). É uma arte acima de tudo, e se o imperativo ético se confunde com o estético, não é para moralizar (SARTRE, 2002, p. 523). Sendo uma forma bela, bela porque livre, ela afere a liberdade alheia à potência de seu empreendimento, passa-lhe "a sua infernal leveza" (SARTRE, 2002, p. 531).

Assim, não se trata de subverter a ordem social ou pervertê-la. Genet se preocupa com sua realização, ela é ao mesmo tempo irrealização do real e só se completa, quando ele consegue estabelecer objetivamente esse gosto singular da conquista de si. O que resta de Genet? Não um valor, nem mesmo a nova 
ordem social, ainda que, enquanto fato social, ela possa vir a modificar o espírito objetivo. Ora, não é uma nova moral, não ao menos intencionalmente, mesmo que sua singularidade se faça soberana. "O que lhes dá em troca? Nada. Um instante de horror, uma beleza suspeita que se desvanece." (SARTRE, 2002, p. 530). Certamente, a obra não é neutra nem nula, ela inflige o ser e só o pode, denotando a ele um novo sentido. Porém, Sartre sabe que não se trata de agora sim coincidir com o bem, se trata tấo somente de mais uma maneira que o ser se faz enquanto possível. Náo há aqui nenhum critério ou valor, senão a imposição que essa finitude se faz. Certamente, Genet re-inventa o crime, a traição (SARTRE, 2002, p. 550), mas tão somente enquanto sua singularidade é vivida como absoluta na sua finitude. Aqui, a negatividade da existência é superposta pela positividade da criação de si. A existência não desagua do nada, pelo contrário, faz desse nada a forma de sua positividade. Mas não porque ela alcança a moral impossível, mas simplesmente porque se faz absoluto na sua singularidade. É a pessoa realizada: "A partir do momento em que narra suas masturbaçôes e seus coitos, há uma felicidade em Genet." (SARTRE, 2002, p. 522). Com isso, fazemos dessa forma uma singularidade, isto é, uma negatividade compreendida no seu peso positivo e que denota mesmo ao espírito objetivo toda a densidade de uma época e as singularidades que dela escapam, ao mesmo tempo que a refazem. Assim, instituem o otimismo de Genet, o peso e a leveza real da liberdade:

O otimismo de Genet vem do fato de que ele nos apresenta o mal, no imaginário, como produzido no ser por uma liberdade. E afinal, pouco importa que o ser tenha este ou aquele sentido. Basta que tenha um. O otimismo não é afirmar que o homem é ou pode ser feliz, mas simplesmente dizer que não é por nada que ele sofre. (SARTRE, 2002, p. 522).

Essa forma totalizada e aberta que repete pela abertura a mesma sinfonia do todo, um todo cuja forma traz a mesma marca, nos coloca o ato poético como ápice da liberdade, enquanto singular relação com a sua alienação, na medida em que essa relação é sua singularidade. Tal é o mal em Genet. Esses momentos, "extraordinários e maravilhosos" (SARTRE, 2007, 521), que conglomeram em si todo um passado e a sua saída subsequente, trazem a marca própria da finitude do finito, pois, se o finito aponta para sua finitude singularizada, singularidade que é dada no mundo, mas cuja ressonância se faz perceber subjetivamente e objetivamente, quando assume a si mesma, isto é, no seu máximo de ser, essa sua qualidade singular nos fornece na sua finitude mesma "a imagem mais clara e mais comovedora de nossa liberdade” (SARTRE, 2007, 
521). É uma imagem que Genet trouxe na sua vida e nos seus textos e que, enquanto trans-histórico, nos restitui esse sabor, esse gosto de uma liberdade.

\section{Conclusão}

Assim, a “impossível salvação pela arte”, apregoada por Sartre nos seus Diários e ratificada por Frajoliet, em seu artigo, é re-encontrada na medida em que o imperativo estético é também o imperativo ético. Em outras palavras, a beleza não implica as formas, mas a forma singular da escolha do indivíduo no seu projeto de ser, portanto, de sua forma de vida singular. Daí que ela seja objeto de uma psicanálise existencial, esta que Merle, no final de seu artigo, considera precária e sem fôlego. Pelo contrário, o interesse do psicanalista é também ético e estético, uma vez que alude às formas, gostos, imagens, símbolos e valores vigentes e ultrapassados pelos indivíduos, em sua época. Sendo a singularidade do indivíduo expressa por seu gosto específico, que não é outra que a forma mesma como decide ser livre, a singularidade da sua liberdade, toda a sua vida pesa nessa constituição em todo o processo dialético na qual ela se engendrou. $\mathrm{Na}$ dialética do universal singular, na luta contra a facticidade da qual se parte, a determinação da escolha não se distingue de toda interiorização e transformação que se passa em seu transcorrer.

Contudo, não se trata mais de salvar o homem da contingência, portando-o de uma idealidade necessária, ou o em-si-para-si, como desejava a totalidade e a beleza em $O$ ser e $o$ nada. Trata-se, antes, da assunçáo dessa contingência pela tomada mesma da finitude. Ou melhor, trata-se simplesmente de viver bem (SARTRE, 2005, p. 45), que aqui não é distinto da bela vida, como já esboçada desde os Diários: "Eu seria moral para realizar a vida mais bela, e não pela moral em si.” (SARTRE, 2005, p. 294). Não estamos pensando aqui a questáo da obra de arte, o que precisaria de um estudo à parte, mas a vida mesma como obra de arte, essas que, quando contadas, como aludia Roquentin, faz com que os homens se envergonhem de sua existência (SARTRE, 2006, p. 220).

PRATES, M. Genet and evil: Sartre between aesthetics and ethics. Trans/form/ação, Marília, v. 42, n. 3, p. 191-218, Jul./Set., 2019. 
ABSTRACT: This article aims to point out a relation between aesthetics and ethics in Sartre, showing that the ethical constitution of the individual does not distinguish from his or her aesthetic constitution. First, we start from Merle's criticism of existential psychoanalysis, and we show how such criticisms can be dismissed on the basis of the encounter with history and the postulation of a theory of personalization in biographical works. Second, we point out how Sartre, in his Saint Genet, ratifies the constitution of a taste regarding the moral by the process of personalization. Finally, we will see that all ethics have a transgressive presupposition insofar as the ethical subject is also an aesthetic subject.

KeYwords: Sartre. Genet. Ethics. Aesthetics. Personalization.

\section{REFERÊNCIAS}

BORNHEIM, G. O idiota e o espirito objetivo. Rio de Janeiro: UAPÊ e SEAF, 1998.

FRAJOLIET, A. Ontologie, morale, histoire. Le Portique, v.16, 2005. Disponível em: http://leportique.revues.org/735. Acesso em: 31 jan. 2017.

MERLE, J.-C. La psychanalyse existentielle et morale chez Sartre. Le Portique, v. 16, 2005. Disponível em: http://leportique.revues.org/731. Acesso em: 31 jan. 2017.

MOUILLIE, J.-M. Sartre: conscience, ego et psyché. Paris: Presses Universitaires de France, 2000.

SARTRE, J-P. A náusea. Rio de Janeiro: Nova Fronteira, 2006.

. Diário de uma guerra estranha. Rio de Janeiro: Nova Fronteira, 2005. . Em defesa dos intelectuais. São Paulo: Ática, 1994.

. Lêtre et le néant: essai d'ontologie phénoménologuique. France: Gallimard, 2007.

. O idiota da familia: Gustave Flaubert de 1821 a 1857. Porto Alegre, RS: L\&PM, 2013. V. 1.

. O idiota da familia: Gustave Flaubert de 1821 a 1857. Porto Alegre, RS: L\&PM, 2014. V.2.

. Saint Genet: ator e mártir. Petrópolis, RJ: Vozes, 2002.

Recebido: 21/02/2017

Aceito: 26/09/2019 